Historic, Archive Document

Do not assume content reflects current scientific knowledge, policies, or practices. 

62.57

\section{BROOKVILLE BLOOMS}

1927

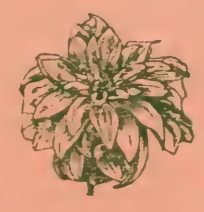

Flowers and Plants for Every Purpose

Grown by

H. W. WEST

2030 Riverside Drive

Trenton, N. J. 


\section{Guaranteed Dahlias That Delight}

\section{DECORATIVE DAHLIAS}

Double loose flowering varieties, full to center, with broad nearly flat petals.

AMUN RA-Immense glistening bloom of sunset gold $\ldots \ldots \ldots \ldots \ldots \ldots 1.00$ AUTUMN'S QUEEN-Charming flower of apricot buff. Fine stem... 2.00 BERTHA JOST-A beautiful soft yellow with pink suffusion ...... 2.50 BONNIE BRAE-Enormous bloom of cream shaded pink ........ 1.00 CHARM-A Judge Marean of glowing orange. Striking form ....... 1.00 EDITH WARD-Bordeaux red. Perfect form on erect stem........ 1.00 EL DORADO-Vivid gold. Ideal in size, stem and color.......... 5.00 ELIZA CLARKE BULL-A beautiful white. Generous bloomer ...... 5.00 ELLINOR VANDERVEER-Immense glowing satiny rose pink...... 5.00 FAITH GARABALDI-Deep rose shading lighter. Good stem and flower 5.00 F. A. KENT-Beautiful staghorn exhibition of mallow pink. Strong... 4.00 HERCULES-A monster. Quilled bloom of tangerine and gold...... 1.50 HIS MAJESTY - A Bessie Boston creation of bright scarlet. . . . . . 5.00 INSULINDE-An upright flower of golden orange............ 1.00 JERSEY'S BEACON-Vigorous producer of huge Chinese scarlet blooms . 5.00 JERSEY'S BEAUTY-A glorious bloom of Erosine pink. Fine stem... 2.00 JUDGE ALTON B. PARKER-A big golden buff, fine for exhibition... 1.50 JUDGE MAREAN-A truly fine decorative. Cerise pink shaded gold.. 1.50 KING SOL_Profuse bloomer of cheerful lemon yellow . . . . . . . . .50 LADY BETTY-Profuse bloomer of pearly white with pink suffusion.. 2.00 LA GROSSE BETE-Enormous flower on stout stems. Cerise red..... 1.00 LILLIAN K.-Splendid pink flower of satiny texture $\ldots \ldots \ldots \ldots \ldots \ldots . .75$

MARCELLE GILL-Not so large, but a fine pink for cutting . . . . . . . .50 MARGARET MASSON-Delightful silvery rose pink. Great depth and size 4.00 MORDELLA-Vividly artistic. Bright apricot buff $\ldots \ldots \ldots \ldots \ldots \ldots$ MR. CROWLEY - Exquisite dahlia of salmon pink and gold .......... MRS. CARL SALBACH-Immense blooms of lavender pink .......... MRS. C. H. BRECK-A bouquet cactus type. Yellow suffused carmine.. MRS. ELEANOR MARTIN-Fine flower. Rose pink flushed with orchid. MRS. F. A. C. PERRINE-Fluffy flower. Lovely lilac with orchid reverse MRS. I. deVER WARNER-A huge charmer of soft orchid ......... MRS. JOHN T. SCHEEPERS-Clear canary yellow shading to pink. Fine MRS. RICHARD LOHRMANN-A curly golden vellow of fine form .... PATTY JANE-Bright rose pink with lighter center. Good cutter.... PAUL MICHAEL-A pure gold prize winner of immense size........

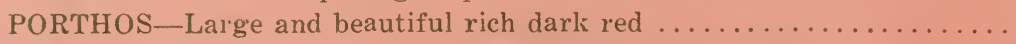
RED PLANET - A big clear cerise slightly tinged sulphur.......... ROBERT TREAT-Gorgeous bloom of brilliant American Beauty ..... ROMAN EAGLE-Exhibition flower of flaming burnished copper ...... SANHICAN'S BLUEBIRD-A noble flower of the nearest approach to blue SANHICAN'S GEM-Large petals of glistening old rose shaded amber.. SHIRLEY OLIVER-Long petals of lovely light rose shaded yellow .... ST. FRA NCIS-Soft cleam color with pinkish glow. Good cutter ..... 
THE MAHDI-Rich carmine streaked with cream. Artistic . . . . . . .75

THE MILLIONAIRE-One of the largest. Dainty lavender pink.....

THEODORE ROOSEVELT-A fiery orange red on upright stem.......

TRENTONIAN-An old gold, amber and coppery bronze monster.....

VENUS-A profuse bloomer of charming rosy lavender ............

WILLIAM SLOCOMBE-Well formed bloom of deep canary..........

1.00

WIZARD OF OZ-Beautiful salmon rose shaded amber toward center.. 3.(4)

WORLD'S BEST WHITE-Large chrysanthemum type of ivory white. . 3.00)

\section{CACTLS AND HYBRID CACTUS DAHLIAS}

Long narrow straight, twisted or incurved petals, pointed and fluted. hybrids are coarser and broader petaled.

ALEX KENNEDY - A fine deep crimson with long strong stems......... ALICE WHITTIER-Huge exhibition hybrid of delicate primrose yellow AMBASSADOR-An enormous stiff stemmed soft yellow buff........

BALLET GIRL-Varicolored combination of orange and white....... BIANCA-Hybrid of orchid pink. Ideal for bouquets ........... BIZARRE-White shaded glowing wine at base. Poor stem but fine form

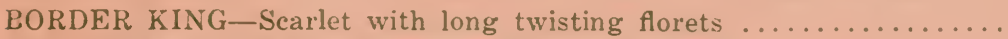
CIGARETTE-Hybrid of creamy orange edged white............. EDITH SLOCOMBE-Finely formed hybrid of garnet and wine........ ESTHER R. HOLMES-A most attractive flower of mauve pink....... FRANCIS LOBDELL-Mallow pink shading to white center. Erect.... F. W. FELLOWS-Coral. Everybody's favorite. Type perfect........ GEORGE WALTERS-The best hybrid. Great bloomer of salmon pink. . JERSEY'S MAMMOTH-A monster hybrid of rich golden mahogany... KALIF-A splendid hybrid of brilliant red $\ldots \ldots \ldots \ldots \ldots \ldots \ldots$ KING SOLOMON-A "Blue Ribbon" hybrid of rich orange buff...... MRS. ETHEL F. T. SMITH-Hybrid of creamy white shading to lemon. . MRS. MARGARET STREDWICK-Rich shrimp pink with extreme incurve NEW MOON-Well formed hybrid. Canary yellow tipped white. Profuse

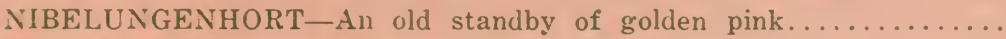
PENNANT-Pronounced incurved type of deep coral..............

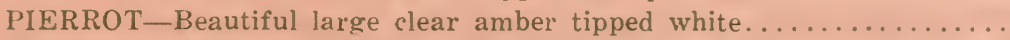
SISKIYOU-Erect monster of mauve pink, tinged gold........... THE BANDIT-Dazzling combination of mahogany red \& pure gold. Hyb. VIOLETTA-A stout stemmed hybrid of petunia violet ........... VULCAN-A fine bold flower of deep maroon, flecked white.......... ZANTE-Hybrid of gold and apricot pink. Large deep flower.......

The

\section{PEONY OR ART DAHLIAS}

Semi-double flowers with open center, whose florets are more or less irregularly twisted.

CAMILLE FRANCHON-A haloed disc of intense rose. Garnet center. .

CITY OF PORTLAND-A strikingly artistic sulphur cactus type...... 
MRS. JOSIAH T. MAREAN-Delightful flutfy flower of genuine old rose 2.50 ROSALIA STYLES - A charming big pink flower on fine stem........ .75

VIOLA M. PARKER-Rich yellow tinted rose. Good for cutting....... . .50

\section{SHOW DAHLIAS}

Globular shaped double flowers, full to the center with finely quilled petals.

A. D. LIVONI-Small but beautifully quilled pink. Fine for bouquets.... CUBAN GIANT-Dark purplish red on splendid stems $\ldots \ldots \ldots \ldots \ldots \ldots$ GOLDEN OPPORTUNITY - A gorgeous giant of pure gold ............ MAUDE ADAMS - Charming flower of white with orchid flush ........ ROBERT LAURIE BLACK - Large hybrid of pure white. Wonderful depth SANHICAN-Immense ball of American Beauty. Prizes every year.... SUPT. AMHRYN-The largest bloom of clear rose. Very fine........

.25

.35

.75

.35

2.00

.75

1.00

\section{POMPOM DAHLIAS}

A miniature symmetrical form not over two inches in diameter.

AMBER QUEEN-Rich amber shaded burnt orange. Most satisfactory.. ARIEL - Rich straw tipped cherry. Wonderful bouquet type.......... BELLE OF SPRINGFIELD_A perfect little gem of brilliant red......

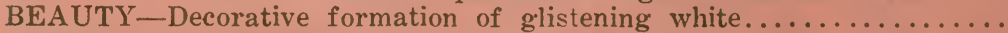
BOBBY - Deep rich purple

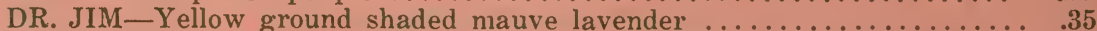
DARKEST OF ALL_The loveliest wine color. Perfection in form..... . .35 EILEEN-Charming little flower of opalescent white........... .25 GLOW-Exquisite light coral rose color. A decided hit............ . .50

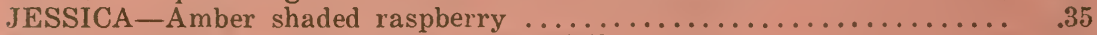

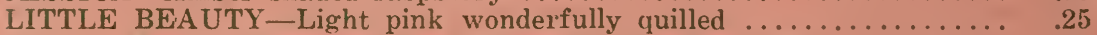
LITTLE MAY - Intense sulphur. Unexcelled for bouquets $\ldots \ldots \ldots \ldots \ldots . .35$

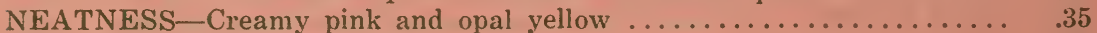

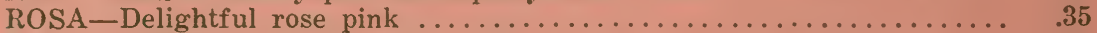

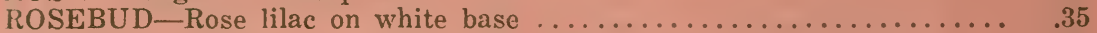
SNOWCLAD - The most perfect pure white. Lavish bloomer......... . .35

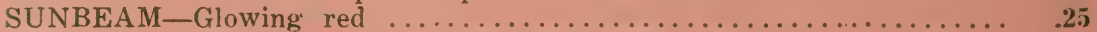
VIVID - Flaming orange red. Sometimes peony type $\ldots \ldots \ldots \ldots \ldots \ldots . .25$

\section{SPECIAI, OFFERS}

12 Finest Decorative Dahlias, surplus stock, all labeled...........\$5.00

12 Best Oactus \& Hy. C. Dahlias, surplus stock, all labeled ......... 4.00

12 Choice Pompom Dahlias, surplus stock, all labeled ............ 2.50

12 Fine Bouquet Dahlias, large types, surplus, all labeled . . . . . . . . 2.50

12 Assorted Dahlias, guaranteed the best, labels lost . . . . . . . . 2.00

100 Mixed Gladiolus-Standard sorts, all blooming size . . . . . . . 2.00

The dahlias here listed are those that have been tried from every angle and found not wanting. Herein you will find the glorious old standbys and the cream of the newer offerings. I can heartily recommend all.

Those "at sea" in regard to selection, may enclose any amount in excess of $\$ 2.49$, with color and type choices indicated and I will forward twelve outstanding sorts, of at least triple value. 